\title{
ANTIOXIDANT ACTIVITY EVALUATION FOR SOME NOVEL CHROMENYL-DERIVATIVES
}

\author{
IOANA IONUT ${ }^{1}$, DIANA OLTEANU ${ }^{2 *}$, GABRIEL MARC ${ }^{1}$, SIMONA CLICHICI ${ }^{2}$, DANIELA \\ BENEDEC $^{3}$, BRINNDUŞA TIPERCIUC ${ }^{1}$, OVIDIU ONIGA $^{1}$ \\ ${ }^{I}$ Pharmaceutical Chemistry Department, Iuliu Haţieganu University of Medicine and Pharmacy, 41 Victor Babeş Street, \\ 400012, Cluj-Napoca, Romania \\ ${ }^{2}$ Physiology Department, Iuliu Hatieganu University of Medicine and Pharmacy, 1 Clinicilor Street, 400006, Cluj-Napoca, \\ Romania \\ ${ }^{3}$ Pharmacognosy Department, Haţieganu University of Medicine and Pharmacy, 12 Ion Creangă Street, 400010, Cluj- \\ Napoca, Romania
}

*corresponding author: olteanu_diana_elena@yahoo.com

Manuscript received: January 2017

\begin{abstract}
A series of twenty previously reported compounds - chromenyl-thiosemicarbazone and chromenyl-dihydro-thiadiazole derivatives - were screened for their in vitro antioxidant activities, using the 2,2-diphenyl-1-picrylhydrazyl (DPPH) method. All chromenyl-thiosemicarbazones (1a-j) exhibited better DPPH scavenging activity than butylated hydroxytoluene (BHT) and two of them (1a and 1h) were superior to ascorbic acid. Therefore, they were further investigated, on human umbilical vein endothelial cells (HUVEC) cells, for their influence on oxidative stress, through the 2'7'-dichlorodihydrofluoresceindiacetate (DCDHF-DA) assay. All chromenyl-thiosemicarbazones tested significantly decreased reactive oxygen species (ROS0 production $\left(\mathrm{p}<0.001\right.$, compared to the group treated only with $\mathrm{H}_{2} \mathrm{O}_{2}$ ).
\end{abstract}

\section{Rezumat}

O serie de douăzeci de compuși raportați anterior - derivați cromonil-tiosemicarbazonici și cromonil-dihidrotiadiazolici - au fost investigați pentru activitatea lor antioxidantă in vitro, prin metoda 2,2-difenil-1-picrilhidrazil (DPPH). Toate cromoniltiosemicarbazonele testate (19-j) au prezentat o activitate antiradicalică superioară butilhidroxitoluen (BHT), iar două dintre acestea (1a şi 1h) s-au dovedit a fi superioare acidului ascorbic. Din acest motiv, tiosemicarbazonele au fost investigate suplimentar, pe celule endoteliale ale venei ombilicale umane (HUVEC), pentru efectul lor asupra stresului oxidativ, utilizând testul 2'7'-diclorodihidrofluorescein-diacetat (DCDHF-DA). Toate cromonil-tiosemicarbazonele testate au redus semnificativ nivelul speciilor reactive de oxigen (SRO) $\left(\mathrm{p}<0.001\right.$, comparativ cu grupul tratat doar cu $\left.\mathrm{H}_{2} \mathrm{O}_{2}\right)$.

Keywords: thiosemicarbazone, thiadiazoline, chromone, antiradicalic activity, oxidative stress

\section{Introduction}

Oxidative stress and its negative effects to the human body are becoming an increasingly important health problem. Oxidative species and free radicals are involved in the physiopathology of numerous diseases like neurodegenerative disorders, cardiovascular, cerebrovascular, autoimmune disorders like diabetes, rheumatoid arthritis, psoriasis. Free radicals are highly reactive and therefore can attack membrane lipids, generating carbon radicals and peroxy radicals, which cause lipid peroxidation. To oppose the vicious effect of free radicals, the body has a number of antioxidant defence mechanisms in the form of enzymes such as superoxide dismutase and catalase [9, 16-18]. Oxidative stress was defined as the lack of balance between the occurrence of reactive oxygen/ nitrogen species (ROS/RNS) and the organism's capacity to counteract their action by the antioxidative protection system [15]. Therefore, various natural as well as synthetic antioxidants are used to scavenge free radicals.

Thiosemicarbazones (TSCs) and thiadiazolines (TDZs) are important classes of nitrogen and sulphur containing compounds and they have been receiving considerable attention in the area of medicinal chemistry because of their promising biological implications and remarkable pharmacological properties $[2,3,20]$. Various TSCs and their heterocyclic TDZ derivatives showed to possess important biological effects, such as antimicrobial, antioxidant, anti-HIV-1 and anticancer, and the literature concerning these subjects is steadily increasing. The presence of fragment $-\mathrm{N}=\mathrm{CH}-\mathrm{R}$ in Schiff bases is known for its biological activity. Many reports exist on structure-activity relationship of the class of these compounds [3, 14]. 1,3,4-TDZ nucleus constitutes the active part of several biologically active compounds, including antibacterial, antifungal, antitubercular, analgesic and antioxidant agents [7, 10]. Chromone and its analogues, an important class of 
oxygen-containing heterocyclic compounds, are abundant in nature and exhibit a wide range of pharmacological activities, as antibacterial, antifungal, anticancer, antioxidant, anti-HIV, anti-inflammatory and immuno-stimulatory. Chromones were found to be active in a number of plant cycles, including growth regulation, indole acetic acid oxidation and dormancy inhibition, as well as exhibiting cytokinintype behaviour and stimulating oxygen uptake in plant tissue $[4,8,18]$. Therefore, the vast range of biological effects associated with these scaffolds resulted in the chromone and 1,3,4-TDZ ring systems being considered as privileged structures.

Based on the above mentioned, it seems worthwhile to continue the investigations in this area. As a continuation of our research on TSC derivatives [6] and nitrogen and sulphur containing heterocycles

$[12,19]$, in the present work, we report the antioxidant potential of some previously reported [5] chromenyl-TSCs as well as of their corresponding 1,3,4-TDZ derivatives, obtained by cyclization under acetylating conditions.

\section{Materials and Methods}

\section{Tested compounds}

Twenty compounds - 10 chromenyl-TSCs (1a-j) and their corresponding 1,3,4-TDZs (2a-j) - were assessed for their in vitro antioxidant activities. The synthesis and physico-chemical characterization of these compounds, along with their in vitro anticancer effects were previously reported [5]. The chemical structures of the tested compounds are compiled in Table I.

Table I

The chemical structures of the investigated compounds

\begin{tabular}{|c|c|c|c|}
\hline & $1 \mathrm{a}-\mathrm{j}$ & & $\left.\right|_{N-N} ^{\mathrm{OCCH}_{3}}$ \\
\hline & ND & $\mathbf{R}_{1}$ & $\mathbf{R}_{\mathbf{2}}$ \\
\hline $1 \mathrm{a}$ & $2 \mathbf{a}$ & $\mathrm{CH}_{3}$ & $\mathrm{CH}_{3}$ \\
\hline 1b & $2 b$ & $\mathrm{Cl}$ & $\mathrm{CH}_{3}$ \\
\hline 1c & $2 \mathrm{c}$ & $\mathrm{CH}_{3}$ & $\mathrm{CH}_{2}-\mathrm{CH}=\mathrm{CH}_{2}$ \\
\hline 1d & $2 d$ & $\mathrm{Cl}$ & $\mathrm{CH}_{2}-\mathrm{CH}=\mathrm{CH}_{2}$ \\
\hline $1 \mathrm{e}$ & $2 \mathrm{e}$ & $\mathrm{CH}_{3}$ & $\mathrm{C}_{6} \mathrm{H}_{5}$ \\
\hline 1f & $2 f$ & $\mathrm{Cl}$ & $\mathrm{C}_{6} \mathrm{H}_{5}$ \\
\hline $1 g$ & $2 \mathrm{~g}$ & $\mathrm{CH}_{3}$ & $4-\mathrm{C}_{6} \mathrm{H}_{4}-\mathrm{OCH}_{3}$ \\
\hline 1h & $2 \mathrm{~h}$ & $\mathrm{Cl}$ & $4-\mathrm{C}_{6} \mathrm{H}_{4}-\mathrm{OCH}_{3}$ \\
\hline $1 \mathrm{i}$ & $2 \mathbf{i}$ & $\mathrm{CH}_{3}$ & $3-\mathrm{C}_{6} \mathrm{H}_{4}-\mathrm{CF}_{3}$ \\
\hline $\mathbf{1 j}$ & $2 \mathrm{j}$ & $\mathrm{Cl}$ & $3-\mathrm{C}_{6} \mathrm{H}_{4}-\mathrm{CF}_{3}$ \\
\hline
\end{tabular}

\section{Antioxidant potential evaluation}

The free radical scavenging activities of these compounds were measured in terms of hydrogen donating or radical scavenging ability, using the stable DPPH (2,2-diphenyl-1-picrylhydrazyl) radical method. The most active compounds were then studied for their influence on oxidative stress using the method of fluorescent 2'7'-dichlorodihydrofluorescein-diacetate (DCDHF-DA).

DPPH Radical Scavenging Assay
The direct antioxidant activity of the twenty compounds was evaluated through a free radical scavenging assay, namely the stable DPPH radical method. The DPPH assay provides an easy and rapid way to evaluate potential antioxidants. The DPPH free radical method is an antioxidant assay based on electron-transfer that produces a violet solution in alcohol. This free radical, stable at room temperature, is reduced in the presence of an antioxidant molecule, giving rise to a yellow solution [11].

Table II

Samples of compounds 1a-j ( $25 \mu \mathrm{g} / \mathrm{mL}$ stock solutions $)$

\begin{tabular}{cccccc} 
Sample & Compound solution $(\mathbf{m L})$ & MetOH $(\mathbf{m L})$ & $\mathbf{D P P H}(\mathbf{m L})$ & Final volume $(\mathbf{m L})$ & Final concentration $(\boldsymbol{\mu g} / \mathbf{m L})$ \\
\cline { 2 - 6 } & 0.25 & 1.75 & 2 & 4 & 1.5625 \\
\cline { 2 - 6 } & 0.50 & 1.50 & 2 & 4 & 3.125 \\
\cline { 2 - 6 } $\mathbf{1 a}-\mathbf{j}$ & 0.75 & 1.25 & 2 & 4 & 4.6875 \\
\cline { 2 - 5 } & 1 & 1 & 2 & 4 & 6.25 \\
\cline { 2 - 5 } & 1.25 & 0.75 & 2 & 4 & 7.8125 \\
\cline { 2 - 5 } & 1.50 & 0.50 & 2 & 4 & 10.9375 \\
\cline { 2 - 5 } & 1.75 & 0.25 & 2 & 4 & 12.5 \\
\hline DPPH & 2 & 0 & 2 & 4 & $0.05 \mathrm{~g} / \mathrm{L}$ \\
\hline
\end{tabular}


Samples of compounds $\mathbf{2 a - j}$ (1 and $0.5 \mathrm{mg} / \mathrm{mL}$ stock solutions) Sample Compound solution $(\mathrm{mL})$ MetOH $(\mathrm{mL})$ DPPH $(\mathrm{mL})$ Final volume $(\mathrm{mL})$ Final concentration $(\mathrm{mg} / \mathrm{mL})$

\begin{tabular}{cccccc}
\hline $\mathbf{2 a}$ & 2 & - & 2 & 4 & 0.5 \\
$\mathbf{2 c}-\mathbf{j}$ & & & & 0.25 \\
\hline $\mathbf{2 b}$ & 2 & - & 2 & 4 & $0.05 \mathrm{~g} / \mathrm{L}$ \\
\hline $\mathbf{D P P H}$ & - & 2 & 2 & 4 & \\
\hline
\end{tabular}

$25 \mu \mathrm{g} / \mathrm{mL}(\mathbf{1} \mathbf{a}-\mathbf{j}), 0.5 \mathrm{mg} / \mathrm{mL}(\mathbf{2 b})$ and $1 \mathrm{mg} / \mathrm{mL}$ (2a, c-j) stock solutions in DMSO (Merck, Darmstadt, Germany) were prepared and then diluted to various concentrations. To these solutions $0.1 \mathrm{~g} / \mathrm{L}$ methanolic solution of DPPH (Sigma Aldrich, USA) was added, at different concentrations. Simultaneously, a control sample was prepared by diluting 1:1 the initial DPPH solution with pure methanol (Merck) (see Table II and Table III). The mixtures where incubated for 30 min at $40^{\circ} \mathrm{C}$ and then the absorbance at $517 \mathrm{~nm}$ was measured.

A decrease in absorbance is associated with the reduction of the DPPH radical and that is directly proportional to the radical scavenging activity of the tested compounds. The DPPH scavenging ability was then calculated for each compound, expressed as a percentage of absorbance reduction, DPPH scavenging ability:

$$
\mathrm{I} \%=\left(\mathrm{A}_{\text {control }}-\mathrm{A}_{\text {sample }} / \mathrm{A}_{\text {control }}\right) \times 100(1) .
$$

Using DPPH scavenging ability $\mathrm{I} \%$, determined (1) at different level of tested compounds concentrations, for the chromenyl-TSC derivatives $\mathbf{1 a - j}$, a curve was plotted in order to calculate the concentrations of compounds that leads to a $50 \%$ reduction of absorbance $\left(\mathrm{IC}_{50}\right)$. This represents the concentration of compound needed to scavenge $50 \%$ of the free DPPH radical. As a positive control we used well known antioxidants, namely butylated hydroxytoluene (BHT) and ascorbic acid. For results interpretations we considered $\mathrm{IC}_{50} \leq 50 \mu \mathrm{g} / \mathrm{mL}$ values as a high antioxidant capacity; $50 \mu \mathrm{g} / \mathrm{mL}<\mathrm{IC}_{50} \leq 200 \mu \mathrm{g} / \mathrm{mL}$ values were considered to reflect a moderate antioxidant capacity and $\mathrm{IC}_{50}>200 \mu \mathrm{g} / \mathrm{mL}$ values were seen as no relevant antioxidant capacity $[1,11]$.

Oxidative stress assessment

Cell culture

Commercial human umbilical vein endothelial cells (HUVEC) from the European Collection of Cell Cultures (ECCAC, Porton Down, Salisbury, UK) were multiplied in RPMI medium, supplemented with
$10 \%$ foetal calf serum (FCS), $50 \mu \mathrm{g} / \mathrm{mL}$ gentamicin, $100 \mu \mathrm{g} / \mathrm{mL}$ amphotericin (Biochrom AG, Berlin, Germany), at $37^{\circ} \mathrm{C}$, in a humidified $\mathrm{CO}_{2}$ incubator. Cell cultures in the $23^{\text {rd }}$ to $26^{\text {th }}$ passages were used [13].

Fluorescent 2'7'-dichlorodihydrofluorescein diacetate (DCDHF-DA)

HUVECs were pre-treated for $24 \mathrm{~h}$ with chromenylTSC derivatives $\mathbf{1 a}-\mathbf{j}$ at a $0.315 \mu \mathrm{g} / \mathrm{mL}$ concentration and then treated with $\mathrm{H}_{2} \mathrm{O}_{2}(10 \mathrm{mM})$ and incubated for $1 \mathrm{~h}$ with fresh medium, and then washed twice before the addition of HBM (HEPES buffered medium) containing DCDHF-DA. Plates were incubated for $30 \mathrm{~min}$ in $5 \% \mathrm{CO}_{2} / 95 \%$ air at $37^{\circ} \mathrm{C}$. After incubation, the cells were washed three times with HBM and the fluorescence was measured using an ELISA plate reader, with excitation at $488 \mathrm{~nm}$ and emission at $525 \mathrm{~nm}$ (Tecan, Männedorf, Switzerland) [13].

Statistical analyses

The statistical significance of the difference between treated and control groups was evaluated with twoway ANOVA, followed by Bonferroni post-test. The significance was set for $\mathrm{p}<0.05$.

\section{Results and Discussion}

Direct antioxidant effect - DPPH scavenging assay The direct antioxidant effect of the tested chromenylderivatives (Table I) was determined using the DPPH free radical method. The DPPH has an odd electron so it can accept an electron or hydrogen free radical. In the presence of an antioxidant, this odd electron becomes paired due to hydrogen transfer from the antioxidant compounds and hence DPPH absorbance decreases. The scavenging ability of the chromenyl-TSCs 1a-j was expressed using $\mathrm{IC}_{50}$ values and is presented in Table IV. Because chromenyl-TDZs 2a-j showed no significant antioxidant potential through this method, their DPPH scavenging ability was expressed only as an inhibition percentage (I\%, Table V).

Table IV

The concentration of compounds $\mathbf{1 a - j}$ needed to scavenge $50 \%$ of the DPPH ( $\left.\mathrm{IC}_{50}\right)$

\begin{tabular}{ccccccccccccc}
\hline Compound & 1a & 1b & 1c & 1d & 1e & 1f & $\mathbf{1 g}$ & $\mathbf{1 h}$ & $\mathbf{1 i}$ & $\mathbf{1 j}$ & BHT & Ascorbic acid \\
\hline $\mathbf{I C}_{\mathbf{5 0}}(\boldsymbol{\mu g} / \mathbf{m L})$ & 7.012 & 8.021 & 8.720 & 8.382 & 11.226 & 9.964 & 8.358 & 6.727 & 10.941 & 10.918 & 16.4 & 7.4 \\
\hline
\end{tabular}

All experiments were performed in triplicate and results are expressed as means, standard deviations were $<5 \%$

Table V

DPPH scavenging activity (\%) determined for compounds $\mathbf{2} \mathbf{a}-\mathbf{j}$

\begin{tabular}{ccccccccccc}
\hline Compound & $\mathbf{2 a}$ & 2b & 2c & 2d & 2e & $\mathbf{2 f}$ & $\mathbf{2 g}$ & $\mathbf{2 h}$ & $\mathbf{2 i}$ & $\mathbf{2 j}$ \\
\hline $\mathbf{I \%}$ & 70.807 & 23.036 & 11.435 & 10.299 & 7.333 & 18.965 & 14.190 & 20.634 & 21.533 & 25.028 \\
\hline
\end{tabular}

All experiments were performed in triplicate and results are expressed as means, standard deviations were $<5 \%$ 
FARMACIA, 2018, Vol. 66, 3

All chromenyl-TSCs presented excellent antioxidant activities, $\mathrm{IC}_{50}$ values ranging between 7 and $11 \mu \mathrm{g} / \mathrm{mL}$. All of them exhibited better DPPH scavenging activity than BHT and two of them (1a and $\mathbf{1 h}$ ) were superior to ascorbic acid. Compound $\mathbf{1 h}$ had the best DPPH scavenging ability. These compounds can be considered as the best compounds in terms of antioxidant activity since $\mathrm{IC}_{50}$ values lower than $10 \mathrm{mg} / \mathrm{mL}$ are usually considered to be effective activities in antioxidant properties [9].
As expected, the results obtained revealed that the cyclization of TSCs $\mathbf{1 a}-\mathbf{j}$ to corresponding TDZs caused a decrease in scavenging ability, probably because the antioxidant potential of these compounds is due to a hydrogen atom transfer (HAT) mechanism. As it can be observed in Figure 1, by cyclization of chromenyl-TSC 1a-j, the mobile hydrogen atoms present in the $N^{2}$ and $N^{4}$ positions disappear.

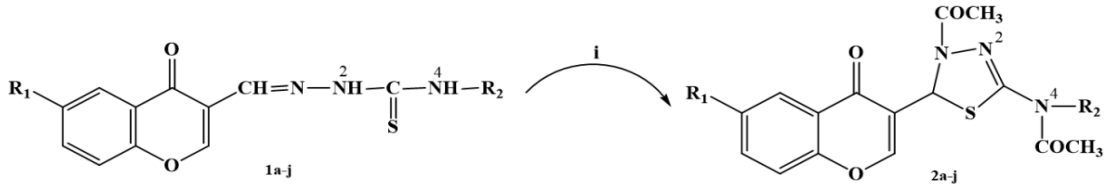

Figure 1.

Disappearance of mobile $\mathrm{H}$ atoms once TSCs 1a-j are cyclized to chromenyl-TDZs $\mathbf{2 a - j}$ (i: $\mathrm{Ac}_{2} \mathrm{O} / \mathrm{Py}, 4$ h, reflux) [5]

SAR analysis indicated that the presence of electron withdrawing substituents $(\mathbf{1 e}, \mathbf{1 f}, \mathbf{1 i}, \mathbf{1 j})$ in position $N^{4}$ of the chromenyl-TSCs slightly reduced the scavenging ability, due to the electron density reduction in positions $N^{2}$ or $N^{4}$, probably both implicated in the hydrogen atom transfer. TSCs substituted with electron donating substituents (alkyl - 1a-d, or methoxy - 1g, 1h) exhibited the best antioxidant effects, most probably due to a better stabilization of the TSC radical thus resulted. In vitro oxidative stress assay on HUVECs

All chromenyl-TSC derivatives $\mathbf{1 a - j}$ (Table I) were supplementary investigated for their influence on oxidative stress.

To assess the production of reactive oxygen species after $1 \mathrm{~h}$ from $\mathrm{H}_{2} \mathrm{O}_{2}$ treatment, the DCDHF-DA assay was used (Figure 2). After treating HUVEC cells with $10 \mathrm{mM}$ of hydrogen peroxide, a significant increase in ROS production, compared to the control group (untreated cells), was found ( $\mathrm{p}<0.001)$.

DCDHF-DA

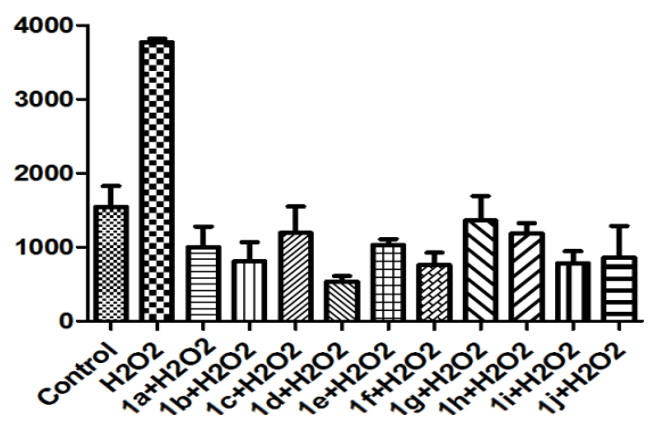

Figure 2.

The level of reactive oxygen species $1 \mathrm{~h}$ after treatment with $\mathrm{H}_{2} \mathrm{O}_{2}$ evaluated on HUVECs cultures pre-treated with compounds $\mathbf{1} \mathbf{a}-\mathbf{j}$, measured using DCDHF-DA
As it can be seen in Figure 2, the ROS generation was decreased after cell exposure to $0.315 \mu \mathrm{g} / \mathrm{mL}$ of all TSCs tested and treatment with $10 \mathrm{mM}$ of hydrogen peroxide, compared to the group that was only treated with $\mathrm{H}_{2} \mathrm{O}_{2}(\mathrm{p}<0.001$ for all the compounds studied). Compared to the control group five compounds (1b, 1d, 1f, 1i, 1j) exhibited a significant $(p<0.01)$ reduction of ROS, $\mathbf{1 d}(p<0.001)$ and $\mathbf{1 f}$ $(\mathrm{p}<0.05)$ being the most active.

\section{Conclusions}

Twenty previously reported chromenyl - derivatives were investigated for their in vitro antioxidant activities. All of the tested chromenyl-TSCs had better DPPH scavenging potential than BHT and some of them were even more potent than ascorbic acid. Their cyclization to chromenyl-TDZs lead to a drastic decrease of the antiradical activity, most probably due to the disappearance of a mobile hydrogen atom. Three of the tested TSC derivatives significantly reduced ROS production in HUVEC cells.

\section{Acknowledgement}

This research was financed by The Executive Agency for Higher Education Research Development and Innovation Funding - UEFISCDI, Romania, on the Contract 210/2014 - Project PN-II-PT-PCCA-20134-2075.

\section{References}

1. Benedec D, Vlase L, Oniga I, Mot AC, Damian G, Hanganu D, Duma M, Silaghi-Dumitrescu R, Polyphenolic composition, antioxidant and antibacterial activities for two Romanian subspecies of Achillea distans Waldst. et Kit. ex Willd. Molecules, 2013; 18(8): 8725-8739.

2. Degola F, Morcia C, Bisceglie F, Mussi F, Tumino G, Ghizzoni R, Pelosi G, Terzi V, Buschini A, 
Restivo FM, Lodi $\mathrm{T}$, In vitro evaluation of the activity of thiosemicarbazone derivatives against mycotoxigenic fungi affecting cereals. Int $J$ Food Microbiol., 2015; 200: 104-111.

3. Ebrahimi HP, Hadi JS, Alsalim TA, Ghali TS, A novel series of thiosemicarbazone drugs: from synthesis to structure. Spectrochim Acta A Mol Biomol Spectrosc., 2015; 137: 1067-1077.

4. Emami S, Ghanbarimasir Z, Recent advances of chroman-4-one derivatives: synthetic approaches and bioactivities. Eur J Med Chem., 2015; 93: 539-563.

5. Ionuţ I, Nastasă C, Ndongo JT, Bruyère C, Leclercqz H, Tiperciuc B, Lefranc F, Pîrnău A, Kiss $\mathrm{R}$, Oniga $\mathrm{O}$, Synthesis and in vitro anticancer activity of new thiadiazolines and thiazolinones containing a chromenyl schaffold. Dig J Nanomater Biostructures, 2013; 8: 1509-1523.

6. Ionuţ I, Nastasă C, Tiperciuc B, Oniga S, Pîrnău A, Vlase L, Colosi I, Duma M, Oniga O, Synthesis and antimicrobial evaluation of some $N^{1}$-Arylidenethiosemicarbazone and 1,3,4-thiadiazoline derivatives. Clujul Med., 2013; 86: 27-33.

7. Ionuţ IA, Tiperciuc B, Oniga O, Szefler B, Maties $\mathrm{R}$, Correlating study on physico-chemical and biological properties of thiosemicarbazone and thiadiazoline derivatives. Stud UBB Chemia, 2012; 57: 109-119.

8. Keri RS, Budagumpi B, Pai RK, Balakrishna RG, Chromones as a privileged scaffold in drug discovery: A review. Eur J Med Chem., 2014; 78: 340-374.

9. Beena, Kumar D, Rawat DS, Synthesis and antioxidant activity of thymol and carvacrol based Schiff bases. Bioorganic Med Chem Lett., 2013; 23(3): 641-645.

10. López-Cara LC, Carrión MD, Entrena A, Gallo MA, Espinosa A, López A, Escames G, AcuñaCastroviejo D, Camacho ME, 1,3,4-Thiadiazole derivatives as selective inhibitors of iNOS versus nNOS: Synthesis and structure-activity dependence. Eur J Med Chem., 2012; 50: 129-139.

11. Mocan A, Crișan G, Vlase L, Crișan O, Vodnar D, Raita O, Gheldiu A-M, Toiu A, Oprean R, Tilea I, Comparative studies on polyphenolic composition, antioxidant and antimicrobial activities of Schisandra chinensis leaves and fruits. Molecules, 2014; 19(9): 15162-15179.
12. Nastasă C, Tiperciuc B, Pârvu A, Duma M, Ionuţ I, Oniga $\mathrm{O}$, Synthesis of New $\mathrm{N}$-Substituted 5-Arylidene2,4-thiazolidinediones as anti-inflammatory and antimicrobial agents. Arch Pharm (Weinheim), 2013; 346(6): 481-490.

13. Olteanu D, Baldea I, Clichici S, Bolfa P, Cenariu M, Schrepler-Perde M, Alupei M, Muresan M, Filip A, In vitro studies on the mechanisms involved in chemoprevention using Calluna vulgaris on vascular endothelial cells exposed to UVB. $J$ Photochem Photobiol B, 2014; 136: 54-61.

14. Parmar N, Teraiya S, Patel R, Barad H, Jajda H, Thakkar V. Synthesis, antimicrobial and antioxidant activities of some 5-pyrazolone based Schiff bases. J Saudi Chem Soc., 2011; 19: 36-41.

15. Pisoschi AM, Pop A, The role of antioxidants in the chemistry of oxidative stress: A review. Eur J Med Chem., 2015; 97: 55-74.

16. Sardina JL, López-Ruano G, Sánchez-Sánchez B, Llanillo M, Hernández-Hernández A, Reactive oxygen species: are they important for haematopoiesis. Crit Rev Oncol Hematol., 2012; 81(3): 257-274.

17. Šarkanj B, Molnar M, Čačić M, Gille L, 4-Methyl7-hydroxycoumarin antifungal and antioxidant activity enhancement by substitution with thiosemicarbazide and thiazolidinone moieties. Food Chem., 2013; 139(1-4): 488-495.

18. Singh M, Kaur M, Silakari O, Flavones: an important scaffold for medicinal chemistry. Eur $J$ Med Chem., 2014; 84: 206-239.

19. Stana A, Vodnar DC, Tamaian R, Pîrnău A, Vlase L, Ionuţ I, Oniga O, Tiperciuc B, Design, synthesis and antifungal activity evaluation of new thiazolin4-ones as potential lanosterol-14alpha-demethylase inhibitors. Int J Mol Sci., 2017; 18(1): 1-25.

20. Yücel Çiğdem, Şeker-Karatoprak Gökçe, Development and evaluation of the antioxidant activity of liposomes and nanospheres containing rosmarinic acid. Farmacia, 2017; 65(1): 40-45.

21. Yusuf M, Kaur M, Jain P, Solanki I, New 1,3,4bisthiadiazolines: synthesis, characterization and antimicrobial evaluations. Spectrochim Acta - Part A Mol Biomol Spectrosc., 2012; 97: 470-447. 